\title{
MECHANISMS OF ZINC, CYSTEINE AND SELENIUM PROTECTION AGAINST CADMIUM-INDUCED VASCULAR INJURY TO MOUSE TESTIS
}

\author{
SAMUEL A. GUNN, THELMA CLARK GOULD \\ AND W. A. D. ANDERSON \\ Department of Pathology, University of Miami School of Medicine, \\ Miami, Florida, U.S.A.
}

(Received 7th November 1966)

\begin{abstract}
Summary. It is known that the selective injurious effect of cadmium on the testis can be prevented by zinc, cysteine or selenium. Studies, conducted in CD-1 mice, were initiated to determine whether any of these treatments offered protection by preventing cadmium from reaching the testis in doses sufficient to cause injury. Using cadmium chloride, labelled with ${ }^{109} \mathrm{Cd}$, it was shown that none of these protective agents decreased the amount of cadmium reaching the testis. Zinc acetate evoked no significant changes, cysteine brought about a slight enhancement of cadmium level but selenium dioxide produced a marked and prolonged elevation of cadmium uptake by the testis. Comparable studies in which selenium, rather than cadmium, was labelled $\left({ }^{75} \mathrm{Se}\right)$ demonstrated that, in the presence of cadmium, selenium levels were augmented. Possible mechanisms are discussed to explain the diverse means of protection offered by zinc, cysteine and selenium. Since the site of cadmium-induced testicular injury has been pin-pointed at its vasculature, it is suggested that these protective agents exert their action at the vascular level.
\end{abstract}

\section{INTRODUCTION}

In a report by Parrizek (1957) it was revealed that the acute toxicity of cadmium to the testis of rats and mice could be prevented by zinc, an observation which has since been confirmed in other laboratories (Kar, Das \& Mukerji, 1960; Gunn, Gould \& Anderson, 1961; Mason, Young \& Brown, 1964). The testis was not protected by treatment with other cations such as sodium, calcium or copper (Pařízek, 1957) but Kar et al. (1960), and later Mason et al. (1964), showed that the metalloid, selenium, was even more efficient than zinc in its prevention of cadmium-induced testicular damage. In a recent publication (Gunn, Gould \& Anderson, 1966) we demonstrated that in the presence of the thiols, cysteine, dimercaptopropanol (BAL) and, to a lesser extent, glutathione, the testis also escaped injury from cadmium. This raised the interesting question of how protection might be offered by this diversity of chemicals and formed the basis for the following investigations. 
This study concerns the distribution of a labelled necrotizing dose of cadmium to mouse testis and how it is influenced by the protective agents, zinc, cysteine and selenium. In order to understand the protective mechanism of selenium better, the experimental procedure also included studies on the radio-active distribution of the protective dose of selenium to testis and how it is influenced by the damaging dose of cadmium.

\section{MATERIALS AND METHODS}

The experimental animals used in these studies were CD-1 male mice purchased from the Charles River Mouse Farms, Inc., North Wilmington, Massachusetts. They were 10 to 12 weeks of age, weighing approximately $40 \mathrm{~g}$, at the beginning of the experimental procedure. A total of 200 mice were used, housed in experimental sets of five mice/cage.

The radio-active chemicals used were obtained from Nuclear Science \& Engineering Corporation, Pittsburgh, Pennsylvania. ${ }^{109} \mathrm{Cd}$ was supplied with a specific activity of $2.37 \mathrm{mc} / \mathrm{mg},{ }^{75} \mathrm{Se}$ with a specific activity of $42 \mathrm{mc} / \mathrm{mg}$.

\section{${ }^{109} \mathrm{Cd}$ distribution to testis}

This series of experiments was designed to answer the question whether the protective agents, zinc, cysteine or selenium, prevent cadmium from reaching the testis in sufficient amounts to cause damage. One group of thirty mice received $10 \mu \mathrm{c}$ of ${ }^{109} \mathrm{Cd}$ in a $0.2 \mathrm{ml}$ subcutaneous injection of $0.0024 \mathrm{M}$ cadmium chloride. This dose of cadmium, $0.012 \mathrm{~m}-\mathrm{mole} / \mathrm{kg}$, had previously been established as the minimum needed to produce complete testicular necrosis by 7 days.

Three other groups of mice (thirty each) received, in addition to this labelled necrotizing dose of cadmium, one of the following treatments which had shown by prior testing to be the minimum needed for complete prevention of testicular necrosis by cadmium: (a) zinc, $0.3 \mathrm{~m}-\mathrm{mole} / \mathrm{kg}$, administered in two subcutaneous doses, each $0.2 \mathrm{ml}$ of $0.03 \mathrm{~m}$ zinc acetate, one given $24 \mathrm{hr}$ before, the other simultaneously with cadmium; (b) cysteine, $6.0 \mathrm{~m}$-mole $/ \mathrm{kg}$, administered as a single $0.8 \mathrm{ml}$ intraperitoneal injection of $0.3 \mathrm{~m}$ solution at the same time as cadmium; and (c) selenium, $0.024 \mathrm{~m}$-mole $/ \mathrm{kg}$, administered as a single $0.2 \mathrm{ml}$ subcutaneous injection of $0.0048 \mathrm{~m}$ selenium dioxide simultaneously with cadmium. When given by the subcutaneous route, the injections of protective compounds were given at a different site from cadmium.

Five mice from each group were killed at varying times ranging from $\frac{1}{2} \mathrm{hr}$ to 7 days. From each mouse, both testes were removed, placed in a $20-\mathrm{ml}$ counting tube containing Bouin's fluid for fixation and their radio-active content was then determined in a well-type scintillation counter. Radio-active uptake in the testes was expressed as a percentage of administered dose/organ. The mean values and standard errors of the mean were calculated for the five mice in each time period. The testes were subsequently processed by routine histological techniques and examined microscopically.

${ }^{75} \mathrm{Se}$ distribution to testis

These studies were initiated to learn more about the distribution of the protective dose of selenium to the testis and how it is influenced by cadmium. 
One group of forty mice received $1 \mu \mathrm{c}$ of ${ }^{75} \mathrm{Se}$ in $0.2 \mathrm{ml}$ of 0.0048 м selenium dioxide, the standard protective dose of selenium. Another group of forty mice received, in addition, the standard damaging dose of cadmium. Five mice from each group were killed at varying times from $\frac{1}{4} \mathrm{hr}$ to 7 days. Testes were processed for radio-active determination and histological examination as described previously.

${ }^{109} \mathrm{Cd}$ studies

\section{RESULTS}

The distribution pattern of radio-active cadmium to testis, shown in Textfig. 1 , indicates that approximately $0.08 \%$ of the administered dose reached the

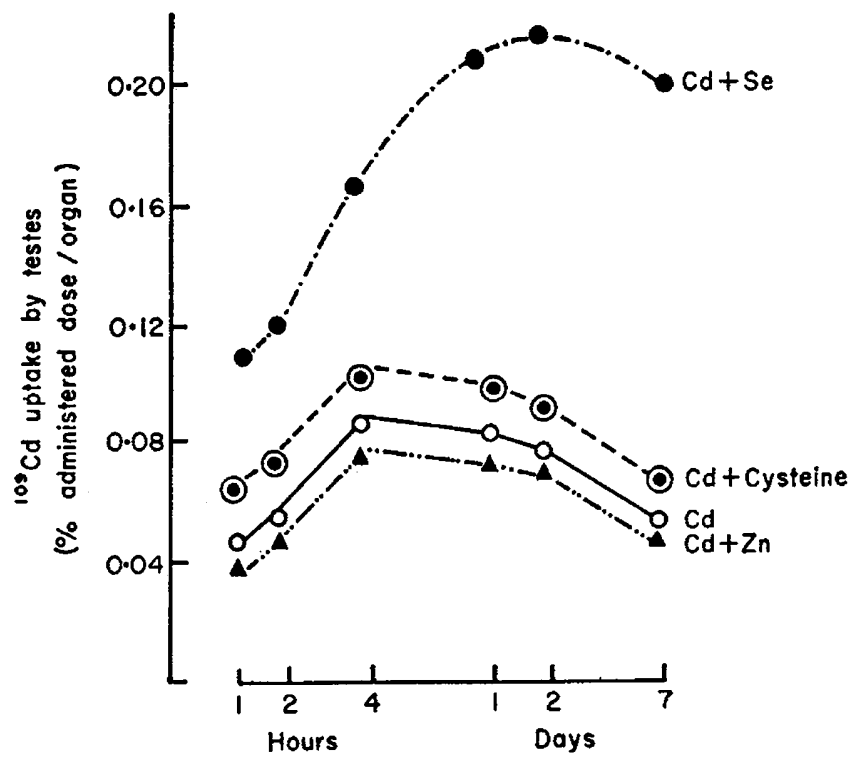

TexT-FIG. 1. The effect of zinc acetate $(0.3 \mathrm{~m}$-mole $/ \mathrm{kg})$, cysteine $(6.0 \mathrm{~m}-\mathrm{mole} / \mathrm{kg})$ and selenium dioxide $(0.024 \mathrm{~m}-\mathrm{mole} / \mathrm{kg})$ on the uptake of ${ }^{109} \mathrm{Cd}$ in cadmium chloride $(0.012$ $\mathrm{m}-\mathrm{mole} / \mathrm{kg}$ ) by testes of $\mathrm{CD}-1$ male mice.

gonad but that these levels were not attained until $4 \mathrm{hr}$ after injection. The figure also reveals that none of the protective agents, zinc, cysteine or selenium, inhibited the amount of cadmium reaching the testis. With zinc treatment, ${ }^{109} \mathrm{Cd}$ uptake was not significantly altered. With cysteine, the amount of cadmium reaching the testis was actually enhanced, a $38 \%$ increase $(P<0.007)$ at the earliest time shown, $1 \mathrm{hr}$, and an $81 \%$ increase $(P<0.006)$ at an earlier distribution time, $\frac{1}{2} \mathrm{hr}$, not shown in the figure. The most startling finding, however, was that in the presence of selenium there was a 150 to $250 \%$ increase $(P<0.005)$ in cadmium uptake by the testis throughout the course of the experiment. And yet, of all the protectors known, selenium is the most potent, completely preventing cadmium damage in a dosage ratio of 2:1 (Kar et al., 1960; Mason et al., 1964).

${ }^{75} \mathrm{Se}$ studies

The results of these experiments, shown in Text-fig. 2, illustrated that approximately $0 \cdot 16 \%$ of the administered dose of selenium reached the testis and 
that this maximum concentration was attained within $\frac{1}{2} \mathrm{hr}$ following injection. In the presence of cadmium, this protective dose of selenium was slowed slightly in its progress to the testis but, by $1 \mathrm{hr}$ after administration, even greater amounts had reached the gonad. From $4 \mathrm{hr}$ on, there was 60 to $90 \%$ greater ${ }^{75} \mathrm{Se}$ level $(P<0.005)$ in the testes of mice which had been treated with cadmium and selenium than in mice which received only selenium.

\section{Histological observations}

Microscopic study confirmed complete testicular necrosis by 7 days following cadmium, and normal-appearing testes in mice given cadmium combined with zinc-, cysteine- or selenium-treatment. There were no morphological changes in testes of mice administered the protective dose of selenium alone.

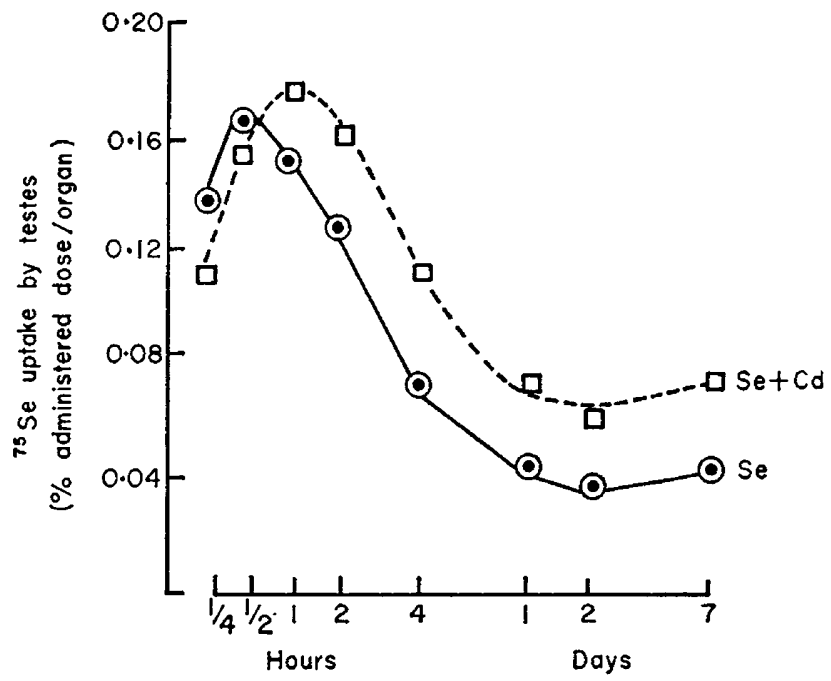

Text-Fig. 2. The effect of cadmium chloride $(0.012 \mathrm{~m}$-mole $/ \mathrm{kg})$ on the uptake of ${ }^{75} \mathrm{Se}$ in selenium dioxide $(0.024 \mathrm{~m}-\mathrm{mole} / \mathrm{kg})$ by testes of CD-1 male mice.

\section{DISGUSSION}

These experiments reveal that the protective treatments of zinc, cysteine and selenium do not act by preventing cadmium from reaching the testis. The fact that zinc does not alter testicular ${ }^{109} \mathrm{Cd}$ uptake, while cysteine and selenium actually enhance it, indicates that the cadmium reaching the testis is somehow inactivated.

It is not surprising that zinc can protect against this cadmium injury for many body tissues are unable to differentiate between the two physico-chemically similar elements (Cotzias, Borg \& Selleck, 1961). Since cysteine, BAL and, to a lesser extent, glutathione have also been found to protect the male gonads from cadmium (Gunn et al., 1966), the implication of thiols in cadmium injury cannot be ignored. Zinc-sulphydryl binding is common in nature, cadmium and zinc are competitive antagonists and the affinity of cadmium for thiols is well documented. 
Although protection afforded by zinc and thiols may be seemingly reconciled, the observation that selenium is an even more efficient preventative demanded further investigation. Kar et al. (1960) had speculated that selenium, like zinc, may play an essential role in testis with which cadmium interferes and that administration of excess selenium may merely overcome this deficiency. But it was shown in the present investigation that the amount of selenium directed to the testis was actually increased by the presence of cadmium. In view of the mutual capacity of cadmium and selenium to augment concentrations of each other in the testis, while at the same time selenium inactivates cadmium, it is tempting to conjecture that some sort of binding exists between the two elements. The affinity of cadmium for certain sulphydryl groups (Simon, Potts \& Gerard, 1947) and the knowledge that selenium frequently follows the biological pathway of sulphur (Rosenfeld \& Beath, 1964) lends weight to the suggestion of a cadmium-selenium complex.

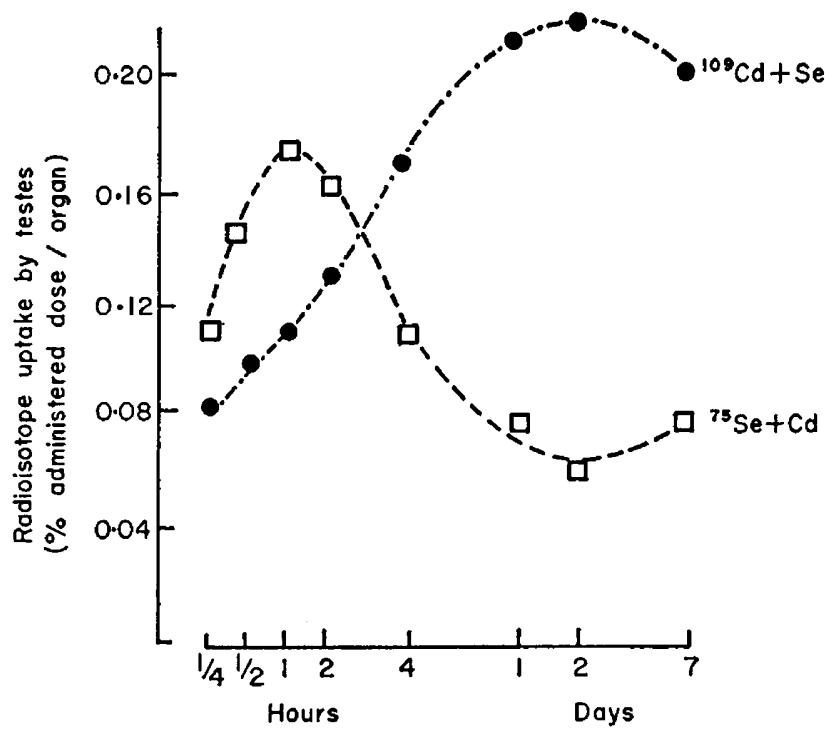

TEXT-FIG. 3. Comparison of the effect of selenium dioxide $(0.024 \mathrm{~m}-\mathrm{mole} / \mathrm{kg})$ on the uptake of ${ }^{109} \mathrm{Cd}$ in cadmium chloride $(0.012 \mathrm{~m}$-mole $/ \mathrm{kg})$ and the effect of cadmium chloride on the uptake of ${ }^{75} \mathrm{Se}$ in selenium dioxide by testes of $\mathrm{CD}-1$ male mice.

To elucidate the cadmium and selenium mechanism further, it is interesting to compare, in composite form (Text-fig. 3), the distribution of these radioactive chemicals in the protected testis. Although the level of both elements initially increases, selenium later leaves while cadmium continues to rise, an implication that selenium has transported cadmium safely in an inactivated form away from the vulnerable site to some other locus within the testis where it is now innocuous.

Cadmium localizes within the endothelial walls of testicular capillaries (Skold, 1961) and several investigators are now in agreement that the primary site of cadmium injury to the testis is on its vascular endothelium (Gunn, Gould \& Anderson, 1963; Chiquoine, 1964; Mason, Brown, Young \& Nesbit, 1964; Niemi \& Kormano, 1965; Waites \& Setchell, 1966). It would seem, then, 
that the protective agents are exerting their counteractive effects at the vascular level. There is considerable evidence that zinc (Strain, 1961; Savlov, Strain \& Huegin, 1962; Strain, Huegin, Lankau, Berliner, McEvoy \& Pories, 1964), thiols (Bennett, 1951; Danielli, Danielli \& Mitchell, 1947; Zweifach, 1961), selenium (Dam \& Glavind, 1940; Rosenfeld \& Beath, 1964) and cadmium (Schroeder, 1965; Carroll, 1966) are associated with vascularity or with circulatory disorders.

\section{ACKNOWLEDGMENTS}

This study was supported by U.S. Public Health Research Grant No. CA07004 from the National Cancer Institute. Some of the results of this investigation were presented at the First International Symposium on Selenium in Biomedicine, Corvallis, Oregon, 6th to 8th September 1966.

\section{REFERENCES}

BennetT, H. S. (1951) The demonstration of thiol groups in certain tissues by means of a new colored sulfhydryl reagent. Anat. Rec. 110, 231.

Carroll, R. E. (1966) The relationship of cadmium in the air to cardiovascular disease death rates. $\mathcal{F}$. Am. med. Ass. 198, 267.

Chiquoine, A. D. (1964) Observations on the early events of cadmium necrosis of the testis. Anat. Rec. $149,23$.

Cotzias, G. C., Borg, D. C. \& Selleck, B. (1961) Virtual absence of turnover in cadmium metabolism: $\mathrm{Cd}^{109}$ studies in the mouse. Am. 7. Physiol. $201,927$.

Dam, H. \& Glavind, J. (1940) Vitamin E und kapillarpermeabilitat. Naturwissenschaften, $28,207$.

Danielli, J. F., Danielli, M. \& Mitchell, P. D. (1947) Bal-Intrav: A new non-toxic thiol for intravenous injection in arsenical poisoning. Biochem. 7. 41, 325.

Gunn, S. A., Gould, T. C. \& Anderson, W. A. D. (1961) Zinc protection against cadmium injury to rat testis. Archs Path. 71, 274.

Gunn, S. A., Gould, T. C. \& Anderson, W. A. D. (1963) The selective injurious response of testicular and epididymal blood vessels to cadmium and its prevention by zinc. Am. F. Path. 42, 685.

Gunn, S. A., Gould, T. C. \& Anderson, W. A. D. (1966) Protective effect of thiol compounds against cadmium-induced damage to testis. Proc. Soc. exp. Biol. Med. 122, 1036.

Kar, A. B., DAs, R. P. \& MukerJI, F. N. I. (1960) Prevention of cadmium induced changes in the gonads of rat by zinc and selenium-a study in antagonism between metals in the biological system. Proc. nain. Inst. Sci. India, B, 26, Suppl., 40.

Mason, K. E., Brown, J. A., Young, J. O. \& Nesert, R. R. (1964) Cadmium-induced injury of the rat testis. Anat. Rec. 149, 135.

Mason, K. E., Young, J. O. \& Brown, J. A. (1964) Effectiveness of selenium and zinc in protecting against cadmium-induced injury of the rat testis. Anat. Rec. 148, 309.

Nremi, M. \& Kormano, M. (1965) An angiographic study of cadmium-induced vascular lesions in the testis and epididymis of the rat. Acta path. microbiol. scand. 63, 513.

Paḱízek, J. (1957) The destructive effect of cadmium on testicular tissue and its prevention by zinc. $\mathcal{F}$. Endocr. 15, 56.

Rosenfeld, I. \& BeAth, O. A. (1964) Selenium, geobotany, biochemistry, toxicity and nutrition. Academic Press, New York.

Savlov, E. D., Strain, W. H. \& Huegin, F. (1962) Radiozinc studies in experimental wound healing. 7. surg. Res. 2, 209.

Schroeder, H. D. (1965) Cadmium as a factor in hypertension. J. chron. Dis. 18, 647.

Simon, F. P., Potts, A. M. \& Gerard, R. W. (1947) Action of cadmium and thiols on tissues and enzymes. Archs Biochem. 12, 283.

Skold, G. (1961) Effect of cadmium poisoning on testes. Acta path. microbiol. scand. 53, 440.

Strain, W. H. (1961) Effects of some minor elements on animals and people. In: Symposium on Geochemical Evolution-the First Five Billion Years. American Association for the Advancement of Sciences, Denver, Colorado.

Strain, W. H., Huegin, F., Lankau, C. A., Berliner, W. P., McEvoy, R. K. \& Pories, W. J. (1964) Zinc-65 retention by aortic tissue of rats. Int. F. appl. Radiat. Isotopes, 15, 231.

Wartes, G. M. H. \& Setchell, B. P. (1966) Changes in blood flow and vascular permeability of the testis, epididymis and accessory reproductive organs of the rat after the administration of cadmium chloride. 7. Endocr. 34, 329.

ZweIfach, B. W. (1961) Functional behavior of the microcirculation. Thomas, Springfield, Illinois. 